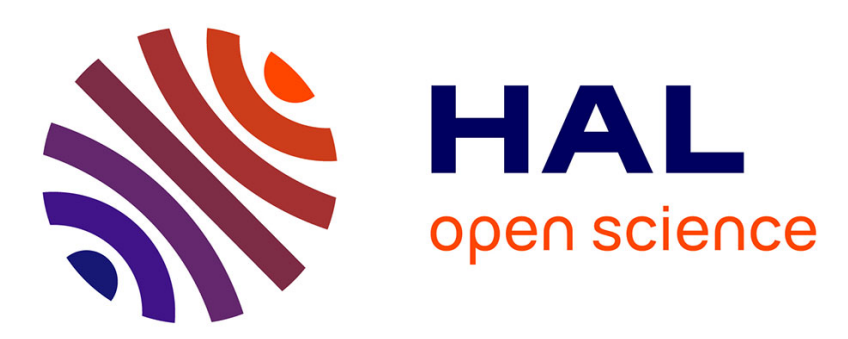

\title{
Design methodologies for sizing a battery bank devoted to a stand-alone and electronically passive wind turbine system
}

Malek Belouda, Amine Jaafar, Bruno Sareni, Xavier Roboam, Jamel Belhadj

\section{- To cite this version:}

Malek Belouda, Amine Jaafar, Bruno Sareni, Xavier Roboam, Jamel Belhadj. Design methodologies for sizing a battery bank devoted to a stand-alone and electronically passive wind turbine system. Renewable and Sustainable Energy Reviews, 2016, vol. 60, pp. 144-154. 10.1016/j.rser.2016.01.111. hal-01290385

\section{HAL Id: hal-01290385 \\ https://hal.science/hal-01290385}

Submitted on 18 Mar 2016

HAL is a multi-disciplinary open access archive for the deposit and dissemination of scientific research documents, whether they are published or not. The documents may come from teaching and research institutions in France or abroad, or from public or private research centers.
L'archive ouverte pluridisciplinaire HAL, est destinée au dépôt et à la diffusion de documents scientifiques de niveau recherche, publiés ou non, émanant des établissements d'enseignement et de recherche français ou étrangers, des laboratoires publics ou privés. 


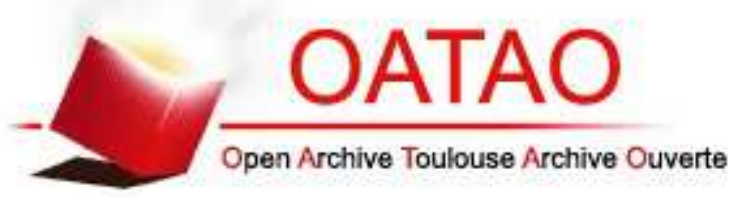

\section{Open Archive TOULOUSE Archive Ouverte (OATAO)}

OATAO is an open access repository that collects the work of Toulouse researchers and makes it freely available over the web where possible.

This is an author-deposited version published in : http://oatao.univ-toulouse.fr/ Eprints ID : 15591

To link to this article : DOI:10.1016/j.rser.2016.01.111

URL : http://dx.doi.org/10.1016/j.rser.2016.01.111

\section{To cite this version :}

Belouda, Malek and Jaafar, Amine and Sareni, Bruno and Roboam, Xavier and Belhadj, Jamel Design methodologies for sizing a battery bank devoted to a stand-alone and electronically passive wind turbine system. (2016) Renewable and Sustainable Energy Reviews, vol. 60. pp. 144-154. ISSN 1364-0321

Any correspondence concerning this service should be sent to the repository administrator: staff-oatao@ listes-diff.inp-toulouse.fr 


\title{
Design methodologies for sizing a battery bank devoted to a stand-alone and electronically passive wind turbine system
}

\author{
Malek Belouda ${ }^{\mathrm{a}, *}$, Amine Jaafar $^{\mathrm{b}}$, Bruno Sareni ${ }^{\mathrm{b}}$, Xavier Roboam ${ }^{\mathrm{b}}$, Jamel Belhadj ${ }^{\mathrm{a}}$ \\ a Université de Tunis, E1 Manar, ENIT - LSE, BP 37, 1002 Tunis le Belvédère, Tunisie \\ ${ }^{\mathrm{b}}$ Université de Toulouse, LAPLACE, UMR CNRS INP-UPS, ENSEEIHT, 2 rue Camichel, BP 71 22, 31071 Toulouse Cedex 07, France
}

Keywords:

Passive wind turbine

Storage

Batteries

Inverse problem

Evolutionary algorithms

Hybrid system

\section{A B S T R A C T}

In this paper, the authors investigate four original methodologies for sizing a battery bank inside a passive wind turbine system. This device interacts with wind and load cycles, especially for a stand-alone application. Generally, actual wind speed measurements are of long duration which leads to extensive processing time in a global optimization context requiring a wide number of system simulations. The first part of this article outlines two sizing methodologies based on a statistical approach for the sizing of the electrochemical storage device of a stand-alone passive wind turbine system. Two other efficient methodologies based on the synthesis of compact wind speed profiles by means of evolutionary algorithms are described in the second part of this paper. The results are finally discussed with regard to the relevance of the battery bank sizing and in terms of computation cost, this later issue being crucial to an Integrated Optimal Design (IOD) process.

\section{Contents}

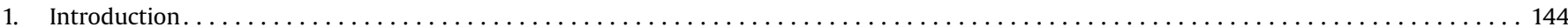

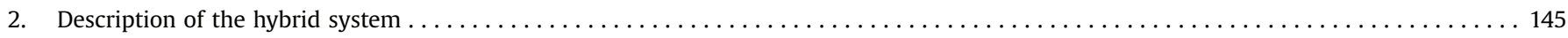

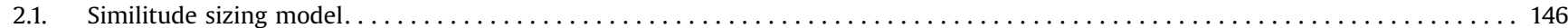

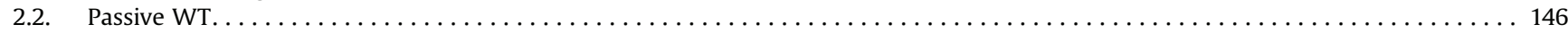

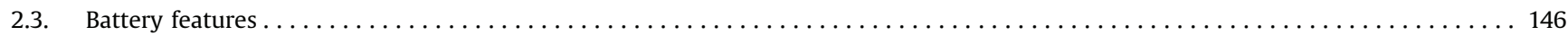

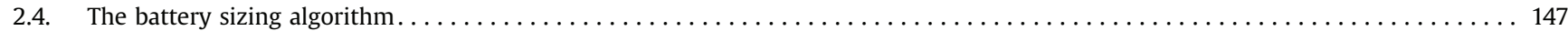

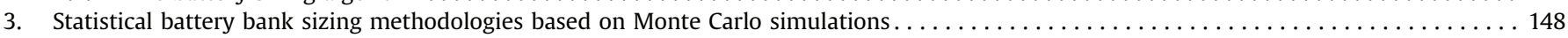

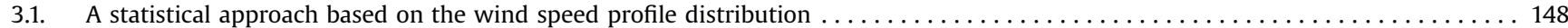

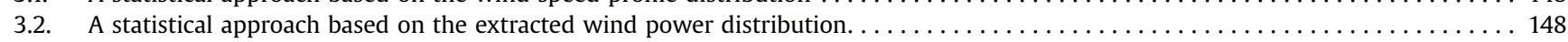

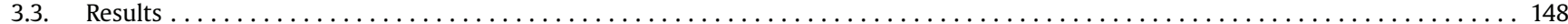

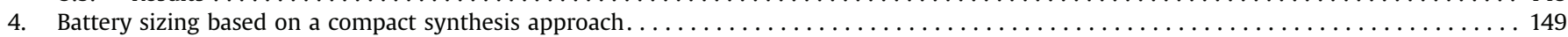

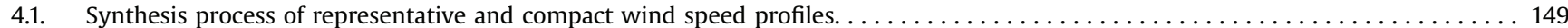

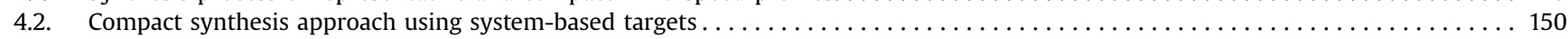

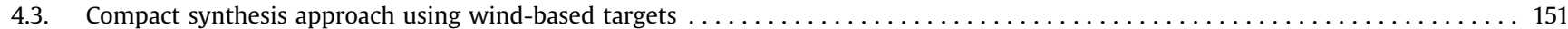

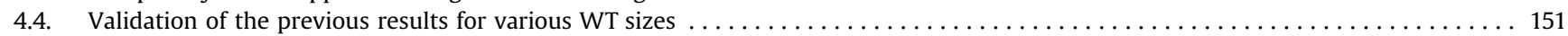

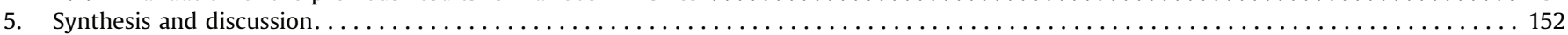

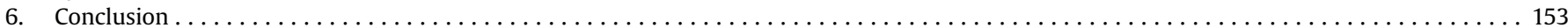

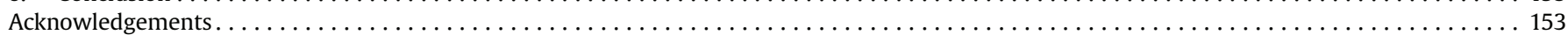

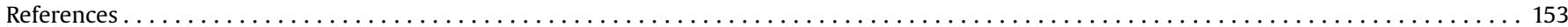

Abbreviations: WT, Wind Turbine; IOD, Integrated Optimal Design; SOC, State Of Charge; DOD, Depth Of Discharge; PMSG, Permanent Magnet Synchronous Generator * Corresponding author. Tel.: +216 71874 700; fax: +216 71872729.

E-mail addresses: malek.belouda@gmail.com (M. Belouda), Jaafar@laplace.univ-tlse.fr (A. Jaafar), sareni@laplace.univ-tlse.fr (B. Sareni), xavier.roboam@laplace.univ-tlse.fr (X. Roboam), jamel.belhadj@esstt.rnu.tn (J. Belhadj). 


\section{Introduction}

Continuity and reliability of electricity supply from wind energy are the two basic criteria for feeding isolated sites. These two criteria can be satisfied by including several types of storage (accumulators, $\mathrm{H}_{2}$ storage, etc.), but this solution is hampered by high ownership costs [1-5]. Thus, providing consumers in remote areas with reliable and cheap electricity depends upon optimal combination and sizing design of the wind generation system coupled with the storage bank. Recently, most optimal configurations are obtained by performing a global optimization process, where a high number of simulations is required [6-14]. However, the unpredictable character of the wind speed presents a significant drawback since the system simulations are carried out over a long period of time. In numerous publications, Bagul, Borowy and Salameh [15-17] have developed several methodologies for optimally sizing a Wind/PV system associated with a battery bank for a given load. These methods are based on the use of long term data for both irradiance and wind speed. Several studies have used the average hourly wind speed data over a few years simulation period. Other researchers [18-20] have developed probabilistic methods to determine the annual energy output of a wind system. In particular in [21], a probabilistic approach was developed to calculate a long term system performance with respect to the average monthly fraction of a load fed by generation systems. In this context, the present study deals with the optimal design of a battery bank for a passive Wind Turbine (WT) system ensuring the continuous supply of an isolated typical farm (see Fig. 1). The design of this system requires taking account of the wind potential and the load demand.

However, the "time phasing" of wind data, generating WT energy/power with the load profile (here a cycle time of $24 \mathrm{~h}$ ), sets a specific problem when sizing the storage device: indeed, the difference between power production and power consumption profiles is not sufficient to characterize the battery sizing. Finding the most critical phasing between WT production and load consumption must be considered. This worst case for the battery sizing will be identified by varying the phase shift between production and consumption profiles. This will be specifically shown in Section 4.3.

In this study, four battery sizing methodologies for a $8 \mathrm{~kW}$ stand-alone passive WT system are investigated. The first two methodologies are based on statistical approaches and consist in determining the constraints (in terms of power and energy needs) associated with the storage system from temporal Monte-Carlobased simulations including wind and load profile variations. The evolution of the wind speed was considered as stochastic while the load profile was deterministically repeated from day to day (Fig. 2). In order to take account of the wind potential features, only slow dynamics related to seasonality have been integrated in the wind profile, i.e. fast dynamics related to turbulence are neglected. Wind features are then represented with a Weibull statistic distribution. Finding the most critical constraints in the storage system requires simulating the system over a long period of time in order to include all correlations between power production and consumption (e.g. time windows with low wind power and high load power and inversely). Such a process is rather expensive in terms of computation cost. It can locally be used to size the battery when the other components of the system (i.e. the passive WT) are known. However, if a global integrated design process is concerned, where all components have to be simultaneously optimized the computation cost of these latter approaches may be problematic. In order to solve this issue, we have investigated two other methodologies for reducing wind profile duration while keeping a trace of wind features in terms of intensity, variability and statistics. This original approach suggested in [22] is adapted for compacting wind speed profiles: it consists in generating compact wind profiles by aggregating elementary parameterized segments in order to fulfill target indicators representing the features of a reference wind profile of longer duration [23]. This inverse problem involving the determination of the segment parameters is solved using an evolutionary algorithm.

The remaining of the paper is organized as follows. The passive wind system and the battery characteristics are described in Section 2. In Section 3, statistical battery bank sizing methodologies are presented. Section 4 is dedicated to the sizing process based on the synthesis approach of a representative and compact wind speed profile. The results obtained from these sizing approaches are summarized and compared in Section 5 in terms of performance (sizing accuracy) and computation cost.

\section{Description of the hybrid system}

The considered system is a $8 \mathrm{~kW}$ full passive WT battery charger without active control and with a minimum number of sensors as studied in $[8,9]$. The deterministic load profile is set for $24 \mathrm{~h}$ and repeated from day to day as indicated in Fig. 2.

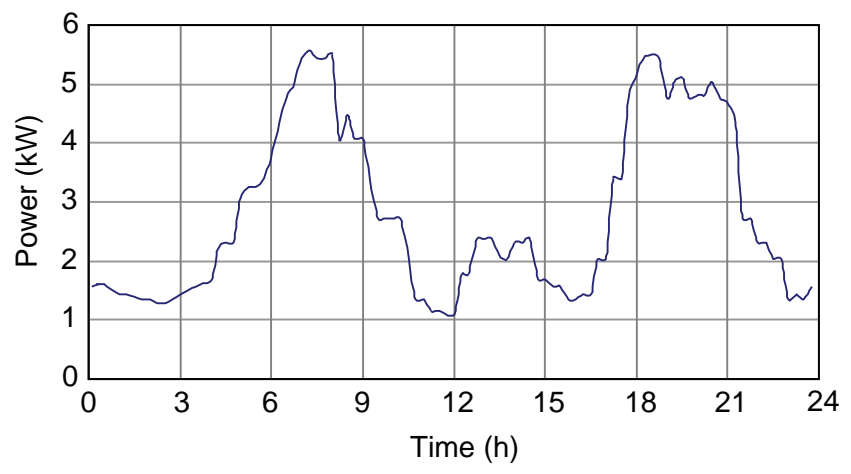

Fig. 2. Typical farm load profile for one day.

\section{Wind turbine}

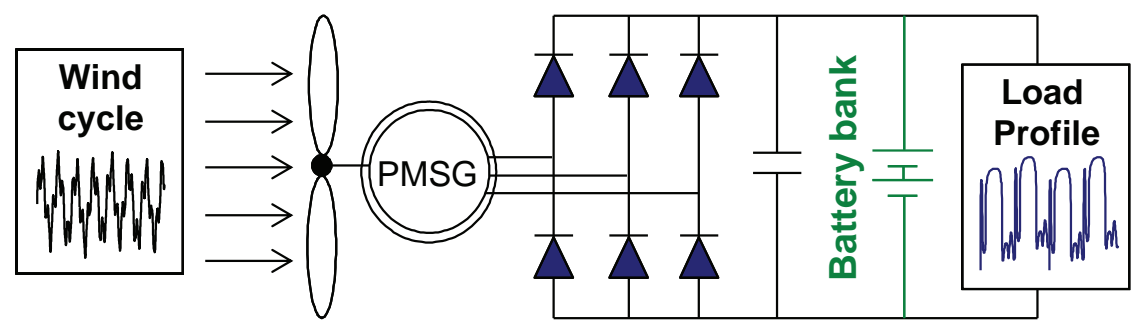

Fig. 1. WT system with battery for stand-alone application (rural site electrification). 


\begin{tabular}{|c|c|c|c|}
\hline \multirow{2}{*}{\multicolumn{2}{|c|}{ Nomenclature }} & $P_{\text {load }}$ & load power \\
\hline & & $N_{d}$ & number of days (in the Monte Carlo simulations) \\
\hline \multicolumn{2}{|l|}{ Symbols } & $\begin{array}{l}N_{B T} \\
<N_{B T}>\end{array}$ & $\begin{array}{l}\text { number of battery cells } \\
\text { average number of battery cells }\end{array}$ \\
\hline$t$ & time step & $T_{C P U}$ & CPU time \\
\hline \multirow{3}{*}{$\begin{array}{l}N_{\text {cycle }} \\
<N_{\text {cycle }} \\
D O D \\
D O D_{\max } \\
S O C\end{array}$} & number of battery cycles & $\Delta t$ & time duration \\
\hline & $\begin{array}{l}\text { average number of battery cycles } \\
\text { battery depth of discharge }\end{array}$ & ref & $\begin{array}{l}\text { index for reference values of powers, energy, } \\
\text { wind speed }\end{array}$ \\
\hline & $\begin{array}{l}\text { battery maximum depth of discharge } \\
\text { battery state of charge }\end{array}$ & compact & $\begin{array}{l}\text { index for the corresponding values of the compact } \\
\text { profile }\end{array}$ \\
\hline \multirow{5}{*}{$\begin{array}{l}\omega_{\text {cycle }} \\
c_{F} \\
N_{\text {rep }} \\
P_{\text {BAT }} \\
P_{\text {BAT MAX }}\end{array}$} & battery cycle weight & $P D F$ & probability distribution function \\
\hline & number of battery cycles to failure & $C D F$ & cumulative distribution function \\
\hline & number of battery replacement & $\varepsilon$ & global error function in the compact synthesis process \\
\hline & battery power & $\varepsilon_{\text {stat }}$ & global error between two cumulative distribution \\
\hline & battery maximum (charge) power & & functions \\
\hline \multirow{6}{*}{$\begin{array}{l}P_{B A T \text { MIN }} \\
E \\
E_{S} \\
T_{a} \\
P_{W T}\end{array}$} & battery minimum (i.e. maximum discharge) power & V & wind speed \\
\hline & battery energy (i.e. actual energy in the battery) & $<V>$ & average wind speed \\
\hline & battery useful energy (i.e. total energy of the battery) & $<V^{3}>$ & average cubic wind speed \\
\hline & battery autonomy (number of hours of autonomy) & $V_{\max }$ & maximum wind speed value \\
\hline & wind turbine power & $V_{\min }$ & minimum wind speed value \\
\hline & & $E_{V}$ & intermittent wind pseudo energy \\
\hline
\end{tabular}

\subsection{Similitude sizing model}

In [9], an integrated optimal design method based on multiobjective optimization has been developed for sizing the elements of a $1.7 \mathrm{~kW}$ passive wind turbine system. In our case, a simplified approach has been preferred based on the exploitation of similitude effects. The new generator dimensions are related to the 'reference' bore radius $r_{\text {sref }}$ and the machine length $l_{\text {rref }}$ of the optimized generator. The reduced parameters $\alpha_{r}$ and $\alpha_{l}$ are introduced:

$\alpha_{r}=\frac{r_{s}}{r_{s \text { ref }}}$

$\alpha_{l}=\frac{l_{r}}{l_{r \text { ref }}}$

where $\alpha_{l}=\alpha_{r}=\sqrt{\frac{P_{\text {new }}}{P_{\text {ref }}}}=2.136\left(P_{\text {new }}=8 \mathrm{~kW}\right.$ and $\left.P_{\text {ref }}=1.7 \mathrm{~kW}\right)$ and where the index ref is associated with the parameters of the reference "optimal" system (i.e. the $1.7 \mathrm{~kW}$ wind turbine system of [9]). Finally, using a similitude-based approach, the PMSG as well as the wind turbine features can be deduced for a $8 \mathrm{~kW}$ passive wind turbine system. Results obtained with this approach will be presented in the following.

\subsection{Passive $W T$}

The $8 \mathrm{~kW}$ passive WT parameters have been obtained by applying the similitude relations. In Tables 1 and 2, the two configuration parameters are summarized.

The WT model is based on a "mixed reduced model" described in [8]: this model neglects the electrical mode effect but simulates the mechanical, especially due to the turbine inertia. In order to simplify the modeling approach and to limit the computation cost, the DC bus voltage is supposed to be constant, whatever the battery state of charge: it has been proved in other studies [8] that this assumption is acceptable and does not question the battery sizing accuracy. This simplified model has been chosen due to its computation efficiency which authorizes analyzing system couplings (WT - battery - load) with environmental (wind cycle) influence.

Fig. 3 shows the extracted power of the new passive WT system obtained by similitude from the reference structure, i.e. a $1.7 \mathrm{~kW}$ optimized passive WT. It can be seen that the quality of wind power extraction of this passive configuration (blue curve) very closely matches the behavior of active WT systems (e.g. [24]) operating at optimal wind powers by using an MPPT control device (i.e. the red cubic curve in Fig. 3). An IXYS VUO190 is considered for the diode bridge rectifier.

\subsection{Battery features}

In this study, a lead acid Yuasa NP 38-12I [26] is considered as battery element. These batteries can be used over a broad temperature range permitting considerable flexibility in system design and location:

- Charge: $-15^{\circ} \mathrm{C}$ to $50{ }^{\circ} \mathrm{C}$

- Discharge: $-20^{\circ} \mathrm{C}$ to $60{ }^{\circ} \mathrm{C}$

- Storage: $-20^{\circ} \mathrm{C}$ to $50^{\circ} \mathrm{C}$ (fully charged battery)

Table 1

Wind turbine parameters.

\begin{tabular}{llc}
\hline & Reference turbine & New turbine \\
\hline Radius $R(\mathrm{~m})$ & 1.25 & 2.67 \\
Friction coefficient $f_{W T}(\mathrm{~N} \mathrm{~m} \mathrm{~s} / \mathrm{rd})$ & 0.025 & 0.52 \\
Inertia $J_{W T}$ & 1.5 & 31.22 \\
Power coefficient $C_{p}$ at MPPT $C_{p}$ opt & 0.441 & 0.441 \\
Tip speed ratio $\lambda$ at MPPT $\lambda_{\text {opt }}$ & 6.9 & 6.9 \\
\hline
\end{tabular}

Table 2

PMSG parameters.

\begin{tabular}{lll}
\hline & Reference generator & New generator \\
\hline Teeth width $w_{t}(\mathrm{~mm})$ & 5.465 & 11.672 \\
Yoke thickness $d_{y}(\mathrm{~mm})$ & 14.096 & 30.098 \\
Number of pole pairs $p$ & 3 & 3 \\
Number of slots per phase per pole $N_{s p p}$ & 3 & 3 \\
Leakage inductance $L_{f}(\mathrm{mH})$ & 0.224 & 0.118 \\
Main inductance $L_{m}(\mathrm{mH})$ & 0.763 & 0.731 \\
Stator inductance $L_{s}(\mathrm{mH})$ & 1.369 & 1.2 \\
Stator flux $\Phi_{s}(\mathrm{~Wb})$ & 0.211 & 0.4708 \\
Stator resistance $R_{S}(\Omega)$ & 0.128 & 0.0148 \\
\hline
\end{tabular}




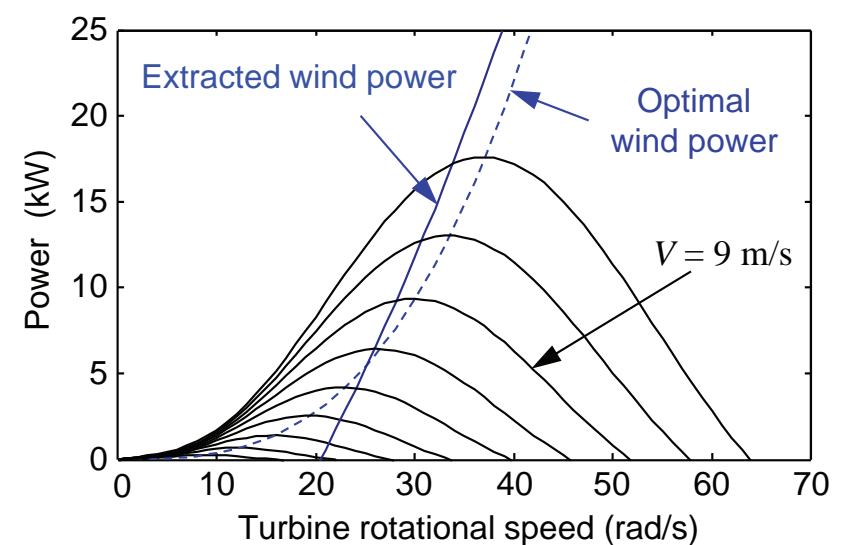

Fig. 3. Extracted power of a $8 \mathrm{~kW}$ passive WT system. (For interpretation of the reference to color in this figure, the reader is reffered to the web version of this article.)

Table 3

Basic characteristics of a Yuasa NP 38-12I lead acid battery element.

\begin{tabular}{ll}
\hline Property & Value \\
\hline Nominal capacity $C_{3}$ & $30.3 \mathrm{~A} \mathrm{~h}$ \\
Nominal voltage $V_{0}$ & $12 \mathrm{~V}$ \\
Nominal discharge Current $I_{3}$ & $10.1 \mathrm{~A}$ \\
Maximum discharge power $P_{\text {dis_max }}$ & $144 \mathrm{~W}$ \\
Maximum charge power $P_{\text {ch_max }}$ & $288 \mathrm{~W}$ \\
\hline
\end{tabular}

The basic characteristics at $20^{\circ} \mathrm{C}$ are summarized in the Table 3 . The estimation of the battery lifetime constitutes a difficult topic which is still a topical issue in the scientific area. The battery lifetime depends on multiple factors such as SOC variations, discharge and charge current rates, ambient conditions (temperature, humidity). In this paper, we use as battery lifetime indicator a simple model based on the cycles to failure curve versus Depth of Discharge (DOD) displayed in Fig. 4. Other factors affecting the battery lifetime are neglected. It should be noted that such approach based on the battery cycling has been used in earlier studies [27-29]. In practice, typical battery state of charge (SOC) evolutions during the system operation are considered. The cycle counting method known as "rainflow" based on Downing's algorithm [30] is then applied for determining the number of cycles $N_{\text {cycle }}$ corresponding to different intervals of DOD (typically the whole DOD range is divided into 10 equally spaced intervals). Finally, the "equivalent" number of full cycles $\left\langle N_{\text {cycle }}\right\rangle$ is calculated as follows:

$<N_{\text {cycle }}>=\sum_{D O D} \omega_{\text {cycle }}(D O D) \times N_{c y c l e}(D O D)$

where the weight $\omega_{\text {cycle }}$ evaluates the effect of a cycle at a given DOD with regard to a cycle at full DOD, i.e.:

$\omega_{\text {cycle }}(D O D)=\frac{c_{F}(100 \%)}{c_{F}(D O D)}$

The number of expected battery replacement $N_{\text {rep }}$ in the system over a given period can be deduced from the corresponding equivalent number of full cycles:

$N_{\text {rep }}=\left\lfloor\frac{<N_{\text {cycle }}>}{C_{F}(100 \%)}\right\rfloor$

where $\rfloor$ denotes the integer part function

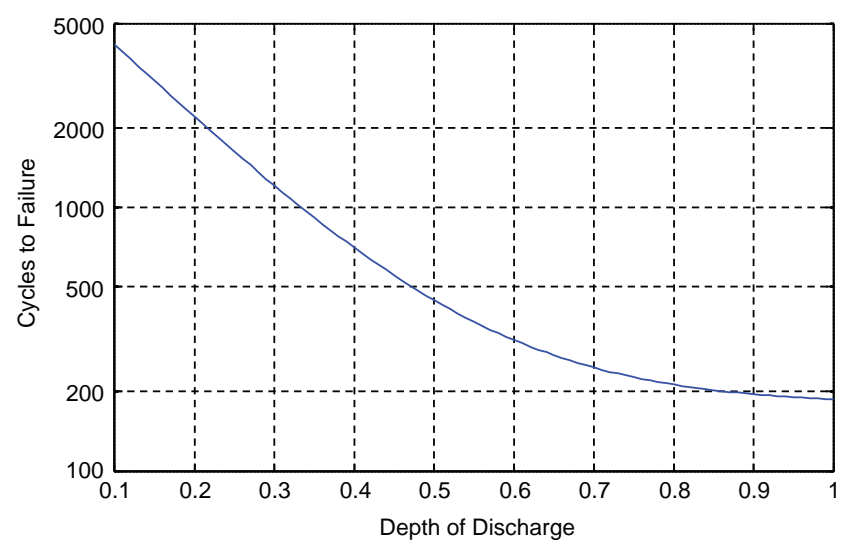

Fig. 4. Cycles to failure curve of the Yuasa accumulator cell.

\subsection{The battery sizing algorithm}

The determination of the battery cell number is based on the energy sizing algorithm explained in detail in [30]. This algorithm computes the active storage energy required for the battery from the corresponding power evolution $P_{B A T}(t)$ while satisfying a maximum depth of discharge $\left(D O D_{\max }\right)$. It is based on an upper saturated integration of the power in the battery bank due to the fact that the charge power is no longer integrated if the battery state of charge is maximal. In such a case, we consider that charge power is wasted in order to avoid the battery bank oversizing. This method is preferred to a simple integration method which generally leads to a battery bank oversizing during wide charge phase (high winds with reduced load). Two operating conditions can be considered for the battery bank sizing: standard operations with wind production. In this case, the battery power can be expressed as the difference between the extracted wind power and the load power (i.e. $P_{B A T}=P_{W T}-P_{\text {load }}$ ). The mechanical wind turbine output power, $P_{W T}(t)(\mathrm{W})$, generated by the wind turbine is $P_{W T}=\frac{1}{2} C_{p} \rho S v^{3}$, where $\rho$ is the air density $\left(\mathrm{kg} \mathrm{m}^{-3}\right), S$ denotes the swept rotor area $\left(\mathrm{m}^{2}\right), v$ represents the wind speed $(\mathrm{m} / \mathrm{s})$ and $C_{p}$ is the power coefficient from manufacturer data corresponding to the turbine studied in [5] and that can be interpolated with: $C_{p}(\lambda)=-$ 3.98.10 $0^{-8} \lambda^{7}-4.21 .10^{-6} \lambda^{6}+2.1 .10^{-4} \lambda^{5}-3.1 .10^{-3} \lambda^{4}+1.64 .10^{-2} \lambda^{3}$ $-0.0176 \lambda^{2}+0.0174 \lambda-1.93 .10^{-3}$

where $\lambda$ is the tip speed ratio which depends on the turbine rotational speed $\Omega(\mathrm{rad} / \mathrm{s})$, on the wind turbine radius $R$ and on the wind speed $v: \lambda=\frac{R \Omega}{v}$

- The resulting power profile in the battery should represent the system behavior over a long period of time and include the stochastic wind features in a particular location (variability and intensity)

- faulty operations without wind production. In this case, the battery power is only related to the load power (i.e. $\left.P_{B A T}=-P_{\text {load }}\right)$ on a desired duration $T_{a}$ representing the number of hours (or the number of days) of autonomy.

It should be noted that the whole system sizing (including the battery sizing) results in an optimization problem with several objectives (cost, autonomy, efficiency, battery lifetime). The investigation of different tradeoffs with regard to some suitable design variables (e.g. WT size, PMSG features, battery $D O D_{\max }$ ) constitutes a specific problem that can be solved using traditional multiobjective optimization methods. Such methods require the iteration of the system sizing and simulation with respect to design variable variations. Nevertheless, they can be applied only if the computational time of the sizing models is acceptable. 
Therefore, the reduction of the complexity and computational time of the battery sizing in standard operations is of prime importance. The remaining of this paper is only focused on this issue. Consequently, in the following sections, the system autonomy and the battery lifetime will result of the battery sizing in standard operations and will not be optimized. The optimization of these criteria with regard to relevant design variables and the investigation of system tradeoffs will be the subject of a complementary ongoing study.

\section{Statistical battery bank sizing methodologies based on Monte Carlo simulations}

\subsection{A statistical approach based on the wind speed profile distribution}

Wind speed data can be predicted by several statistical distributions models from the wind energy potential at a particular location. In this first approach, the sizing process is based on the generation of a wind cycle from its statistical distribution [32]. The continuous temporal wind speed profiles are generated from a statistical distribution. A certain number of samples are generated with a random number generator according to the established statistical distribution. The continuous temporal profiles are then obtained by interpolating the generated samples. The synoptic of the random process generation of the wind speed cycles is illustrated in Fig. 5.

As previously mentioned, the battery bank sizing is related to the level of power and energy which depend on the magnitude and phase of wind potential and of the load demand. In order to determine the relevant battery bank sizing, i.e. when the system is under the "worst" case conditions (maximum power and energy), several wind speed profiles with increasing duration have to be generated until the battery sizing is stabilized. This sizing is then obtained when the number of battery cells required to supply the load becomes quasi-constant.

The synoptic of this battery bank sizing process is shown in Fig. 6. The issue consists in producing 11 wind cycles with a progressive duration from 1 to 200 days. These cycles are synthesized from a given wind statistic (i.e. a particular Weibull distribution) during $N_{d}$ days $\left(N_{d}=\{1,2,3,10,20,30,50,70,100,150,200\right.$ days $\}$ ). Subsequently, after having simulated the WT system by means of the "mixed-reduced model", 11 extracted wind powers $\left(P_{W T}\right)$ are generated. The load power $\left(P_{\text {load }}\right)$ is daily repeated during the $N_{d}$ days.

The number of battery elements and the computational time $\left(T_{\mathrm{CPU}}\right)$ under different wind speed profiles are given in Table 2 . The computational time is the time needed by the processor to simulate the system model and to perform the battery sizing process. The corresponding system autonomy and the battery lifetime indicator, consisting in the equivalent number of full cycles extrapolated over 20 years, are given in Table 3 .

\subsection{A statistical approach based on the extracted wind power distribution}

With the aim of reducing the computational time, an essential factor in an IOD context, this approach consists in directly generating the extracted power $\left(P_{W T}\right)$ histogram instead of the wind histogram as previously proposed. For each interval of wind speed, the corresponding extracted power is estimated by simulating the passive wind system (the extracted power is synthesized on the same timescales as with the first approach).

From wind statistics, the histogram of $P_{W T}$ is built. Therefore, the WT power profile is directly obtained from its distribution by means of random number generation and interpolation techniques exactly as previously for the wind time cycle generation. Following this step, from histogram of powers, the output WT power can be directly generated before obtaining the battery power used for the storage bank sizing process (Fig. 7). The storage bank sizing process is quite similar to the first approach, i.e. producing $11 \mathrm{~W}$ power cycles with a progressive duration from 1 to 200 days and waiting until the number of battery cells becomes quasi-constant.

\subsection{Results}

The results obtained from both statistical approaches are compared in Table 4 and in Table 5 with regard to the battery sizing, the CPU time, the system autonomy and the lifetime indicator. A first analysis of these results shows that $\left\langle N_{B T}\right\rangle$ becomes quasi-constant and does not exceed 132 battery elements for a number $N_{d}>70$ days in both approaches (see Fig. 8). This "optimal duration threshold" is sufficient for taking wind variability into account (i.e. stochastic features of wind) and to obtain a suitable and robust sizing for the battery bank. It can be observed from Table 3 that it also leads in both approaches to the same number of battery cycles which approximately equals 380 and represents 2 battery replacements in the system over 20 years. Finally, the second approach offers a notable reduction of computational time,

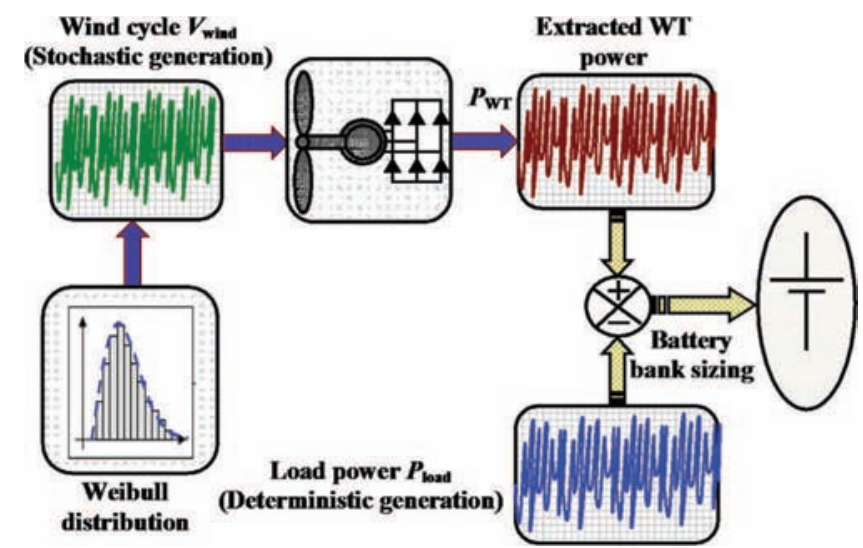

Fig. 6. Battery bank sizing process based on a wind profile generation from its statistical distribution.

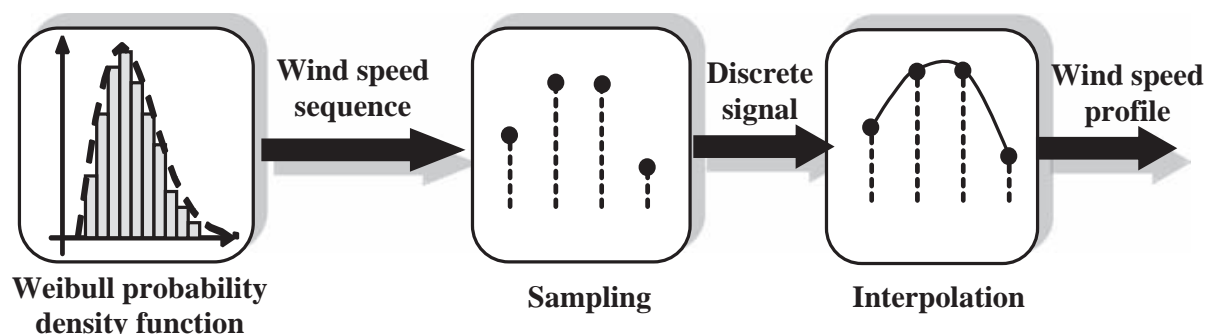

Fig. 5. Wind speed cycle generation. 


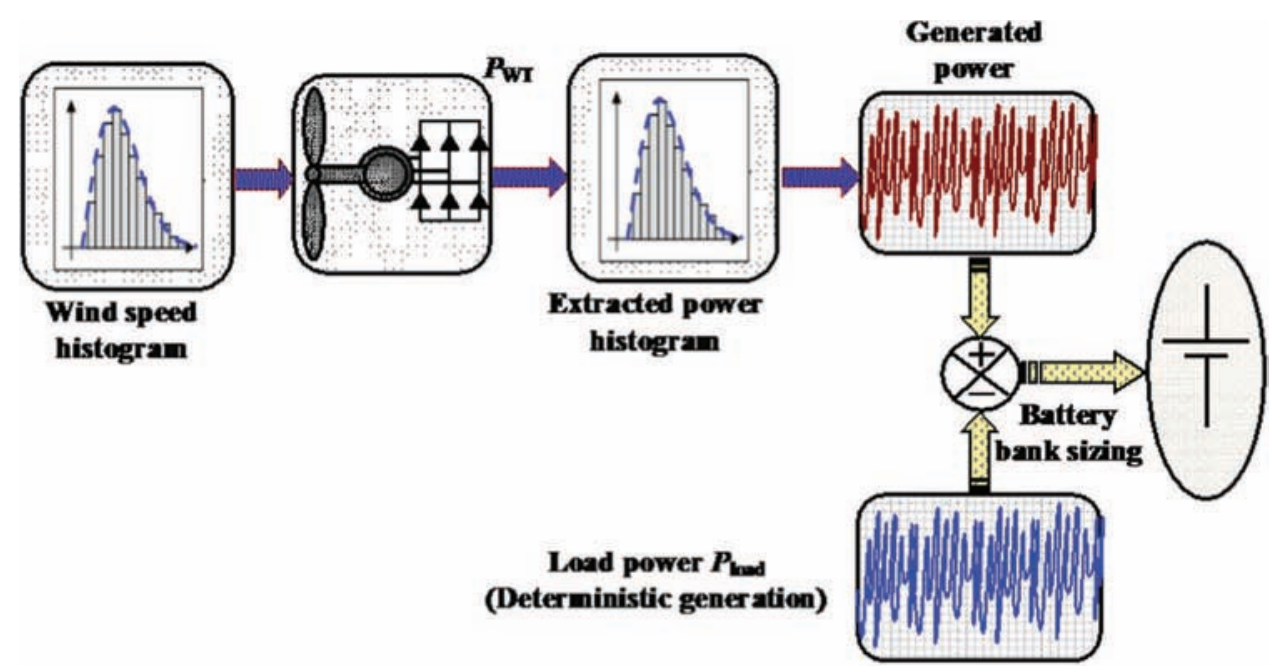

Fig. 7. Battery bank sizing process based on an extracted power generation profile from its statistical distribution.

Table 4

Results obtained from statistical approaches with Monte Carlo simulations - CPU time and average number of battery cells.

\begin{tabular}{|c|c|c|c|c|}
\hline \multirow[t]{2}{*}{$\begin{array}{l}\text { Number of } \\
\text { days }\end{array}$} & \multicolumn{2}{|l|}{ CPU Time (s) } & \multicolumn{2}{|c|}{$\begin{array}{l}\text { Average number of battery cells } \\
<N_{B T}>\end{array}$} \\
\hline & $\begin{array}{l}\text { Wind speed- } \\
\text { based } \\
\text { approach }\end{array}$ & $\begin{array}{l}\text { Output WT } \\
\text { power-based } \\
\text { approach }\end{array}$ & $\begin{array}{l}\text { Wind speed- } \\
\text { based } \\
\text { approach }\end{array}$ & $\begin{array}{l}\text { Output WT } \\
\text { power-based } \\
\text { approach }\end{array}$ \\
\hline 1 & 0.10 & 0.06 & 46 & 45 \\
\hline 2 & 0.19 & 0.17 & 54 & 57 \\
\hline 3 & 0.29 & 0.26 & 61 & 61 \\
\hline 10 & 0.56 & 0.31 & 88 & 88 \\
\hline 20 & 0.78 & 0.32 & 97 & 98 \\
\hline 30 & 1.21 & 0.41 & 109 & 114 \\
\hline 50 & 3.06 & 0.58 & 117 & 118 \\
\hline 70 & 4.57 & 0.83 & 130 & 129 \\
\hline 100 & 7.06 & 1.32 & 126 & 127 \\
\hline 150 & 12.80 & 2.47 & 126 & 124 \\
\hline 200 & 19.23 & 4.00 & 132 & 131 \\
\hline
\end{tabular}

e.g. for 70 days results showed a decreased rate of 5.5 on the CPU time during the system simulation: simulations are performed with a standard computer (Core Duo $1.7 \mathrm{GHz}$ ).

\section{Battery sizing based on a compact synthesis approach}

In this section, a "compact synthesis process" is applied on an actual wind speed profile of 200-day duration considered as reference data, with the aim of generating a compact profile of reduced duration $\Delta t_{\text {compact }}$. Two different approaches are investigated depending on the choice of the target indicators used for generating the fictitious compact wind speed profile in order to establish its correspondence with reference data.

\subsection{Synthesis process of representative and compact wind speed profiles}

The synthesis process of compact wind profiles is based on the approach developed in [22]. It consists in generating a fictitious profile of any environmental variable (e.g. temperature, wind speed, solar irradiation, driving cycle profile) by fulfilling some constraints related to "target indicators" (typically minimum, maximum and average value, probability distribution). These indicators can be evaluated from a set of reference cycles usually of
Table 5

Results obtained from statistical approaches with Monte Carlo simulations - lifetime indicator and system autonomy.

\begin{tabular}{|c|c|c|c|c|}
\hline \multirow[t]{2}{*}{$\begin{array}{l}\text { Number of } \\
\text { days }\end{array}$} & \multicolumn{2}{|c|}{ System autonomy (h) } & \multicolumn{2}{|c|}{$\begin{array}{l}\text { Number of cycles (over } 20 \\
\text { years) }\end{array}$} \\
\hline & $\begin{array}{l}\text { Wind speed- } \\
\text { based } \\
\text { approach }\end{array}$ & $\begin{array}{l}\text { Output WT } \\
\text { power-based } \\
\text { approach }\end{array}$ & $\begin{array}{l}\text { Wind speed- } \\
\text { based } \\
\text { approach }\end{array}$ & $\begin{array}{l}\text { Output WT } \\
\text { power-based } \\
\text { approach }\end{array}$ \\
\hline 1 & 4.8 & 4.7 & 648 & 653 \\
\hline 2 & 6 & 6 & 477 & 463 \\
\hline 3 & 6.3 & 6.3 & 469 & 469 \\
\hline 10 & 9.1 & 9.1 & 408 & 408 \\
\hline 20 & 10 & 10.2 & 411 & 411 \\
\hline 30 & 11.3 & 11.8 & 410 & 414 \\
\hline 50 & 12.2 & 12.2 & 391 & 391 \\
\hline 70 & 13.3 & 13.3 & 375 & 376 \\
\hline 100 & 13 & 13.1 & 386 & 384 \\
\hline 150 & 13.1 & 12.8 & 374 & 374 \\
\hline 200 & 13.4 & 13.2 & 372 & 373 \\
\hline
\end{tabular}

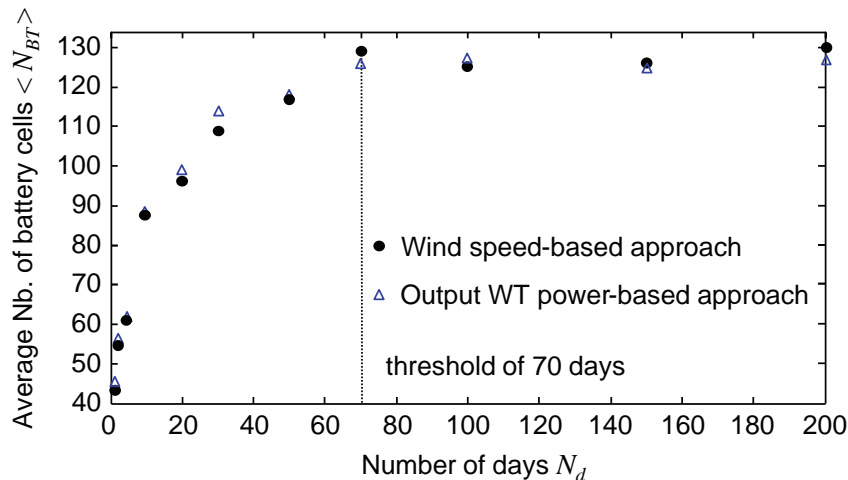

Fig. 8. Battery sizing versus the number of days of simulations.

long duration: here we have considered a 200-day wind profile. This fictitious profile is obtained by aggregating elementary segments as shown in Fig. 9. Each segment is characterized by its amplitude $\Delta S_{n}\left(\Delta S_{\text {minref }} \leq \Delta S_{n} \leq \Delta S_{\text {maxref }}\right)$ and its duration $\Delta t_{n}$ $\left(0 \leq \Delta t_{n} \leq \Delta t_{\text {compact }}\right)$. A time scaling step is performed after this profile generation in order to fulfill the constraint related to the time duration, i.e. $\Sigma \Delta t_{n}=\Delta t_{\text {compact }}$. Finding a compact fictitious profile of an environmental variable consists in finding all segment parameters so that the generated profile fulfills all target 

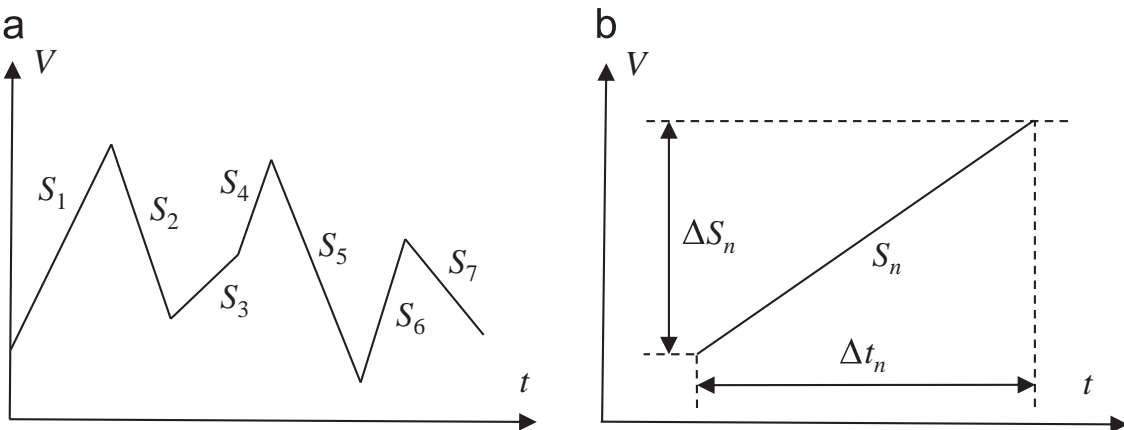

Fig. 9. Principle of the wind profile synthesis (a) wind profile generated by elementary segments (b) segment parameters.

indicators (with respect to the reference data) on the reduced duration $\Delta t_{\text {compact }}$. This results in solving an inverse problem with $2 N$ parameters where $N$ denotes the number of segments in the compact profile. This has been achieved using evolutionary algorithms and more especially with the clearing method [33] well suited to deal with this kind of problem with high dimensionality and high multimodality. It should also be noted that the number $N$ of segments can itself be optimized through a self-adaptive procedure [22]. The target indicators are defined to characterize the signal (minimum, maximum, average values, probability density function) but they can also be related to the design context (here, the WT system has to charge a battery bank for which maximum power and energy range are relevant).

\subsection{Compact synthesis approach using system-based targets}

The first compact synthesis approach is based on the use of target indicators related to the storage system features. In this approach, the global sizing of the storage system is related to the three following variables: $P_{B A T M A X}, P_{B A T M I N}$ and $E_{S}$ which respectively denote the maximum and the minimum storage powers in the battery $P_{B A T}(t)$ and the maximum energy quantity imposed on this storage. These variables are extracted from the simulation of a $8 \mathrm{~kW}$ passive WT system over the reference profile of $\Delta t_{\text {ref }}=200$ days and used as target indicators in the synthesis process. Note that the reference value of the storage useful energy $E_{\text {Sref }}$ is defined as follows:

$E_{\text {Sref }}=\max E(t)-\min E(t)$

with $E(t)=\int_{0}^{t} P_{B A T}(\tau) d \tau \quad t \in\left[0, \Delta t_{r e f}\right]$ where $E(t)$ is a saturated integral, with 0 as upper limit so that the battery storage is only sized in discharge mode to avoid oversizing during a long charging period (high winds with reduced load). An additional target indicator is considered to take account of statistic features of the reference wind cycle. We use the Cumulative Distribution Function $C D F\left(V_{\text {ref }}\right)[23]$ computed from the corresponding probability density function $\left(P D F_{r e f}\right)$ related to the reference wind speed behaviour. $P D F_{r e f}$ is evaluated on 20 equally spaced intervals between 0 and the maximum wind speed value $V_{\text {refmax. }}$ Finally, the global error $\varepsilon$ to be minimized in the synthesis profile process can be expressed as:

$\epsilon=\left(\frac{P_{\text {BATMAX }}-P_{\text {BATMAX ref }}}{P_{\text {BATMAX ref }}}\right)^{2}+\left(\frac{P_{\text {BATMIN }}-P_{\text {BATMIN ref }}}{P_{\text {BATMIN ref }}}\right)^{2}+\left(\frac{E_{S}-E_{\text {Sref }}}{E_{\text {Sref }}}\right)^{2}+\epsilon_{\text {stat }}$

where the statistic error $\varepsilon_{\text {stat }}$ denotes the mean squared error between both $C D F$ s relative to reference and generated wind speed profiles:

$\varepsilon_{\text {stat }}=\frac{1}{20} \times \sum_{k=1}^{20}\left(\frac{C D F(k)-C D F_{\text {ref }}(k)}{C D F_{\text {ref }}(k)}\right)^{2}$

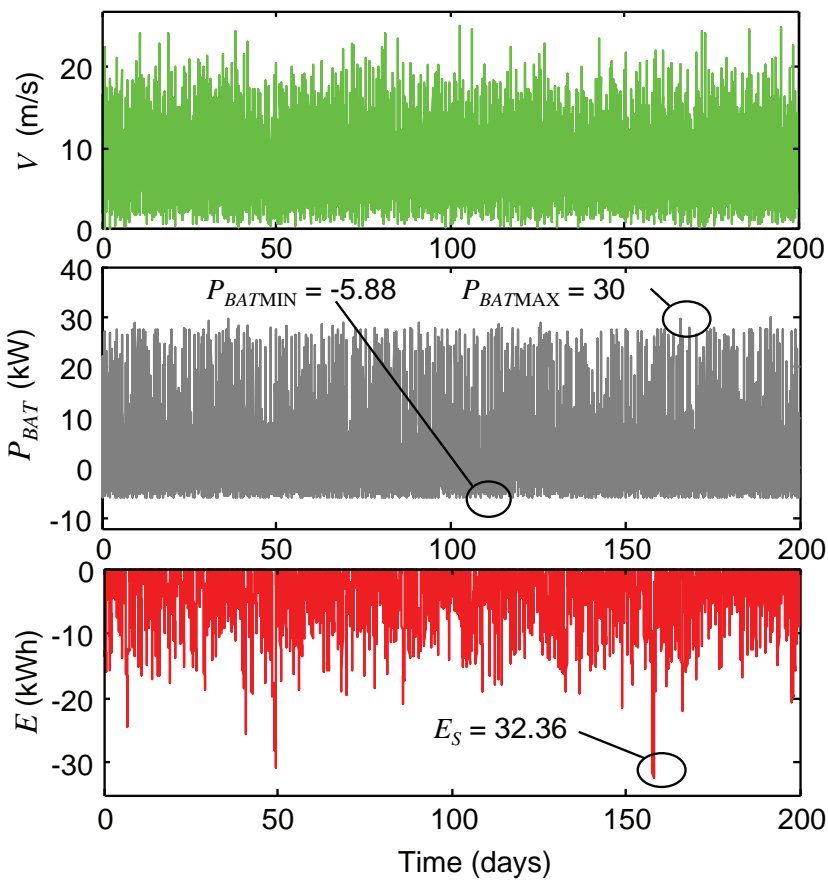

Fig. 10. Actual "reference" wind speed profile, corresponding storage power and energy.

All 'ref' indexed variables are based on the reference wind profile of Fig. 10. The inverse problem is solved with the clearing algorithm [33] using a population size of 100 individuals and a number of generations of 500,000. Multiple optimization runs are performed with different compaction times $\Delta t_{\text {compact. }}$. In particular, the minimum compaction time (i.e. min $\Delta t_{\text {compact }}$ ) was determined using a dichotomous search in order to ensure a global error $\varepsilon$ less than $10^{-2}$. Table 6 shows the values of the global error $\varepsilon$ versus the compaction time. It can be seen that the lowest value for $\Delta t_{\text {compact }}$ ensuring the fulfillment of the target indicators with sufficient accuracy is about 10 days. Fig. 11 displays the characteristics of the generated wind profile obtained from the aggregation of 109 elementary segments fulfilling all target indicators. It can be seen from this figure that the $C D F$ of this compact wind profile closely coincides with that of the reference wind profile.

Table 7 compares the values of the target indicators related to the battery sizing for the reference profile and the fictitious profile generated with the clearing algorithm. A good agreement between those values indicates that the compact wind profile would certainly lead to the same battery sizing as with the reference wind profile over a longer period. This will be verified in Section 5 . Finally, it should be noted that the equivalent number of full cycles resulting from the fictitious wind profile and extrapolated over 20 
years is 385. This number is coherent with the reference values obtained in Table 5 with wind profiles of longer duration.

\subsection{Compact synthesis approach using wind-based targets}

In this second approach, the selected target indicators are only related to the wind features: this approach can be considered as generic in the case of any WT system whatever its sizing. We firstly consider three indicators $V_{\max }, V_{\min }$ and $\left\langle V^{3}>\right.$ representing the maximum and minimum speed values and the average cubic wind speed value. Note that $\left\langle V^{3}\right\rangle$ is used instead of the average wind speed value $\langle V\rangle$ because the WT power is directly proportional to the cubic wind speed value. Similarly to the previous approach, we also add the $C D F$ as a target indicator associated with the wind profile in order to take the wind statistic into account. Finally, we consider as the last indicator related to "wind energy" the variable $E_{V}$ defined as:

$$
E_{V}=\max _{t \in[0, \Delta t]} E(t)-\min _{t \in[0, \Delta t]} E(t)
$$

with $E(t)=\int_{0}^{t}\left(V^{3}(\tau)-<V^{3}>\right) d \tau \quad t \in[0, \Delta t]$

$E_{V}$ represents an "intermittent wind pseudo energy". In fact, $E_{V}$ plays a similar role with $E_{S}$ in the previous approach for the storage system. Note that the wind power being proportional to $V^{3}, E_{V}$ is not actually energy (in Joules or $\mathrm{kWh}$ ) but can be seen as a "pseudo energy" which is qualitatively related to the wind energy. The global error $\varepsilon$ to be minimized with this second approach can be expressed as:

$$
\begin{aligned}
\varepsilon & =\left(\frac{V_{\max }-V_{\max r e f}}{V_{\max r e f}}\right)^{2}+\left(\frac{V_{\min }-V_{\min r e f}}{V_{\min r e f}}\right)^{2} \\
& +\left(\frac{<V^{3}>-<V^{3}>\text { ref }}{<V^{3}>_{\text {ref }}}\right)^{2}+\left(\frac{E_{V}-E_{V \text { ref }}}{E_{V \text { ref }}}\right)^{2}+\varepsilon_{\text {stat }}
\end{aligned}
$$

where $\varepsilon_{\text {stat }}$ is computed according to Eq. (7) and where the reference intermittent wind energy $E_{V r e f}$ is scaled according to the compact profile duration:

$E_{V \text { ref }}=\frac{\Delta t_{\text {compact }}}{\Delta t_{\text {ref }}} \times E_{V r e f}\left(\Delta t_{\text {ref }}\right)$

Table 6

Influence of $\Delta t_{\text {compact }}$ on the global error $\varepsilon$

\begin{tabular}{lllll}
\hline$\Delta t_{\text {compact }}$ (days) & 40 & 20 & 10 & 5 \\
\hline Global error $\varepsilon$ & $\approx 8.10^{-3}$ & $\approx 9.10^{-3}$ & $\approx 9.10^{-3}$ & $\approx 7.10^{-2}$ \\
\hline
\end{tabular}

\section{a}

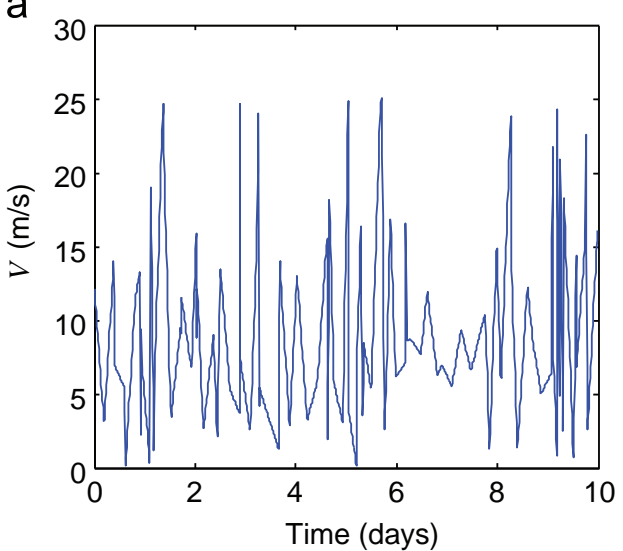

The inverse problem is solved with the clearing algorithm with the same control parameters as in the previous subsection. Multiple optimization runs were performed with different compaction time $\Delta t_{\text {compact. }}$ The minimum value for this variable ensuring a global error of less than $10^{-2}$ was identical to that found with the previous approach (i.e. 10 days). Fig. 12 shows the characteristics of the generated wind profile obtained for $\Delta t_{\text {compact }}=10$ days, from the aggregation of 130 elementary segments fulfilling all target indicators. The good match between the compact generated profile and the reference profile can also be observed in this figure in terms of $C D F$. Finally, Table 8 shows that the values of the target indicators are very close in both cases. For comparison with the previous approach, we also give the sizing of the battery obtained from the simulation of the compact profile. It should be noted that contrary to the first approach, the second does not include phase correlations between wind and load profiles because it only considers wind speed variations to generate the compact wind speed profile. Consequently, the second approach does not ensure finding the most critical constraints on the storage device in terms of production - load phase shift. This can be a posteriori done by sequentially shifting the obtained wind profile to its 10 day time window in compliance with the deterministic load profile repeated from day to day. The maximum storage energy quantity $E_{S}$ is computed for each phase shift and the highest (most critical) value is returned (see Fig. 13). In this way, a value of $34.4 \mathrm{kWh}$ is obtained for $E_{S}$ which is very close to that resulting from the reference profile simulation (i.e. $32.3 \mathrm{kWh}$ ).

Finally, we mention that the equivalent number of full cycles resulting from the fictitious wind profile and extrapolated over 20 years is 398 , close to the previous values obtained with the other approaches.

\subsection{Validation of the previous results for various WT sizes}

In order to validate the effectiveness of the previous approaches, the compact wind profiles obtained in both methods are used to estimate the battery sizing for various WTs. Three WTs are

Table 7

Target indicators of the generated wind speed profile.

\begin{tabular}{llll}
\hline & $\begin{array}{l}\text { Reference profile (200 } \\
\text { days) }\end{array}$ & $\begin{array}{l}\text { Compact profile (10 } \\
\text { days) }\end{array}$ & Error (\%) \\
\hline$P_{\text {BATMAX }}(\mathrm{kW})$ & 30 & 30 & 0 \\
$P_{\text {BATMIN }}(\mathrm{kW})$ & -5.88 & -5.82 & 0.1 \\
$E_{S}(\mathrm{kWh})$ & 32.36 & 32.4 & 0.12 \\
\hline
\end{tabular}

b

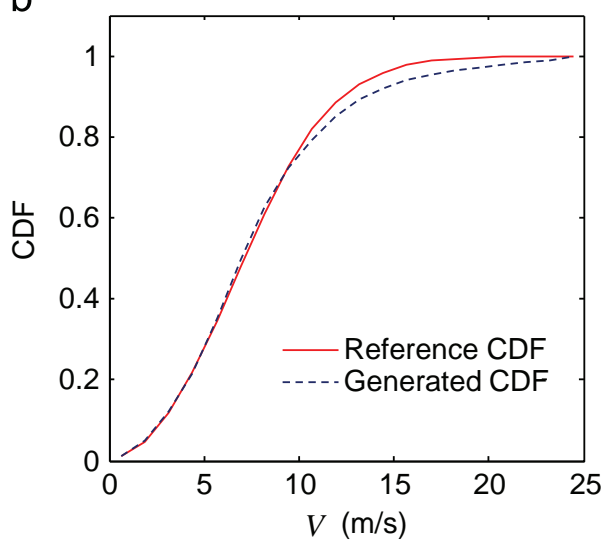

Fig. 11. Generated wind speed profile (a) with corresponding CDF (b). 
a

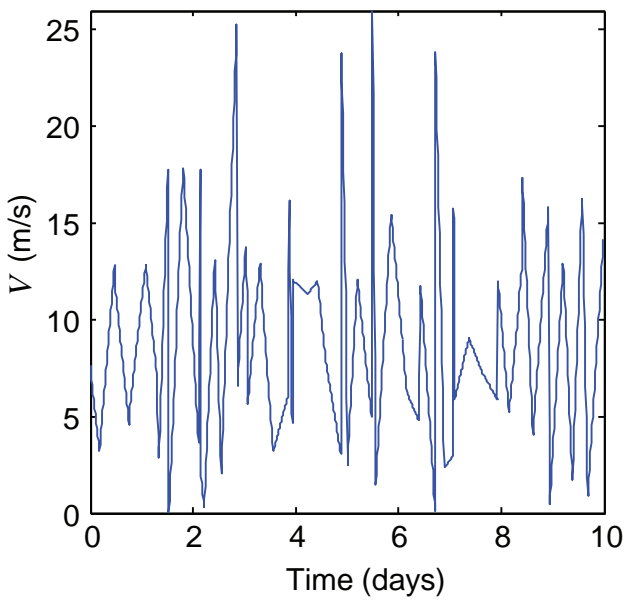

b

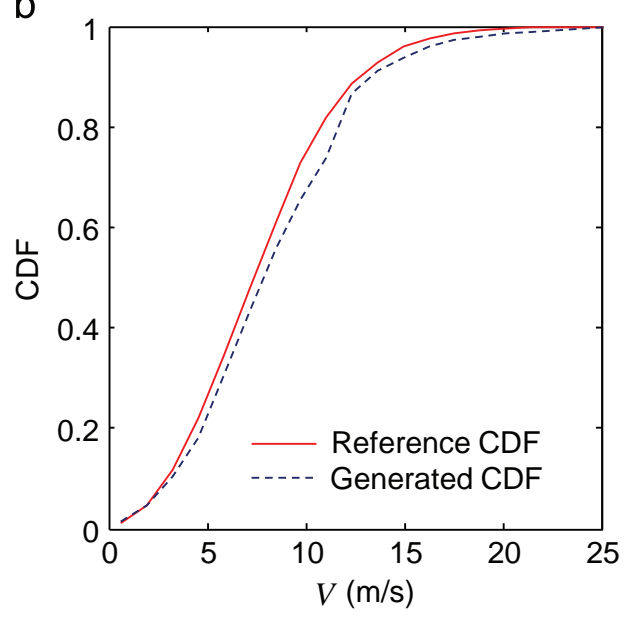

Fig. 12. Generated wind speed profile (a) with corresponding CDF (b).

Table 8

Target indicators of the generated wind speed profile.

\begin{tabular}{llll}
\hline & $\begin{array}{l}\text { Reference profile (200 } \\
\text { days) }\end{array}$ & $\begin{array}{l}\text { Compact profile (10 } \\
\text { days })\end{array}$ & Error (\%) \\
\hline$V_{\max }(\mathrm{m} / \mathrm{s})$ & 25.1 & 25.9 & 3.58 \\
$V_{\min }(\mathrm{m} / \mathrm{s})$ & 0 & 0 & 0 \\
$<V^{3}>\left(\mathrm{m}^{3} / \mathrm{s}^{3}\right)$ & 876.4 & 871.4 & 0.57 \\
$E_{V}\left(\mathrm{~m}^{3} / \mathrm{s}^{2}\right)$ & 32.3 & 34.4 & 0.42 \\
\hline
\end{tabular}
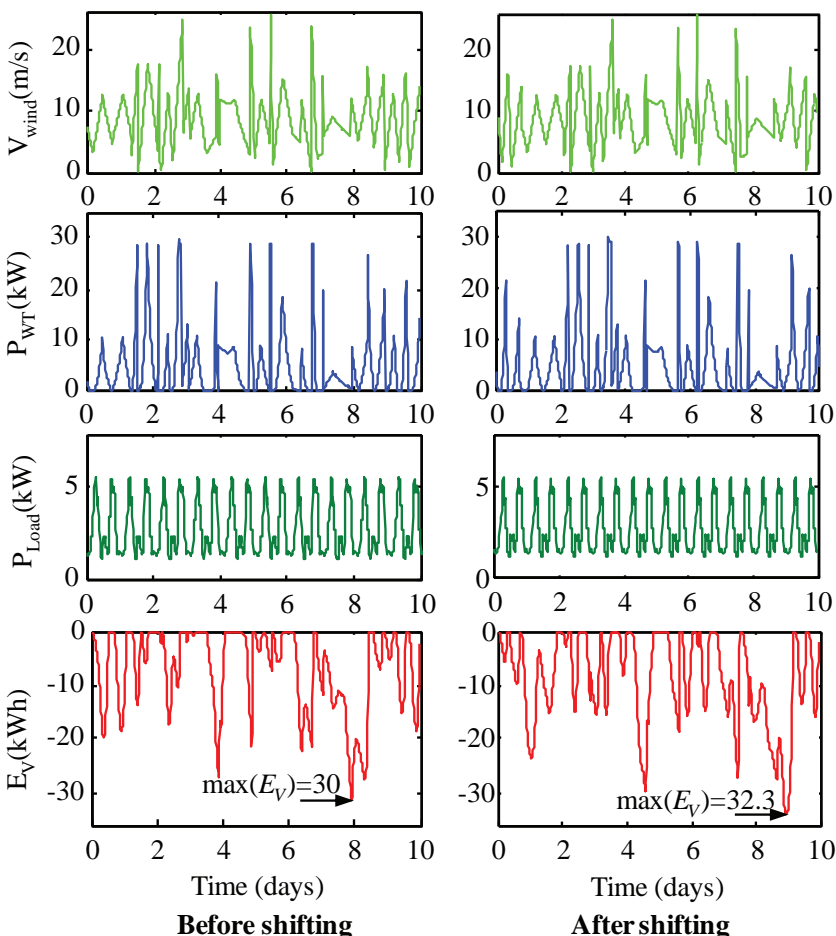

Fig. 13. Illustration of the phase shift of the wind speed profile (generated with the wind-based compact synthesis approach) on the battery sizing.

considered with nominal power of $7 \mathrm{~kW}, 8 \mathrm{~kW}$ and $9.5 \mathrm{~kW}$. The tables below summarize the results obtained for the battery sizing variables (i.e. $P_{\text {BATMAX }}, P_{B A T M I N}$ and $E_{S}$ ) for each WT sizing with the reference profile of 200 days duration and with the compact profiles resulting from both approaches developed in the previous sections. A good match between those variables is obtained in all cases whatever the WT sizing. This indicates that compact profiles
Table 9

Results obtained for a $7 \mathrm{~kW}$ passive WT.

\begin{tabular}{lccc}
\hline & $\begin{array}{l}\text { Reference profile } \\
\text { (200 days) }\end{array}$ & $\begin{array}{l}\text { System-based tar- } \\
\text { gets (10 days) }\end{array}$ & $\begin{array}{l}\text { Wind-based tar- } \\
\text { gets (10 days) }\end{array}$ \\
\hline$P_{\text {BATMAX }}(\mathrm{kW})$ & 26.3 & 26.3 & 26.3 \\
$P_{\text {BATMIN }}(\mathrm{kW})$ & -5.88 & -5.83 & -5.83 \\
$E_{S}(\mathrm{kWh})$ & 46.9 & 46.2 & 46.8 \\
\hline
\end{tabular}

Table 10

Results obtained for a $8 \mathrm{~kW}$ passive WT.

\begin{tabular}{llll}
\hline & $\begin{array}{l}\text { Reference profile } \\
\text { (200 days) }\end{array}$ & $\begin{array}{l}\text { System-based tar- } \\
\text { gets (10 days) }\end{array}$ & $\begin{array}{l}\text { Wind-based tar- } \\
\text { gets (10 days) }\end{array}$ \\
\hline$P_{\text {BATMAX }}(\mathrm{kW})$ & 30 & 30 & 30 \\
$P_{\text {BATMIN }}(\mathrm{kW})$ & -5.88 & -5.82 & -5.2 \\
$E_{S}(\mathrm{kWh})$ & 32.36 & 32.40 & 34.40 \\
\hline
\end{tabular}

Table 11

Results obtained for a $9 \mathrm{~kW}$ passive WT.

\begin{tabular}{llll}
\hline & $\begin{array}{l}\text { Reference profile } \\
\text { (200 days) }\end{array}$ & $\begin{array}{l}\text { System-based tar- } \\
\text { gets (10 days) }\end{array}$ & $\begin{array}{l}\text { Wind-based tar- } \\
\text { gets (10 days) }\end{array}$ \\
\hline$P_{\text {BATMAX }}(\mathrm{kW})$ & 34.8 & 34.8 & 34.8 \\
$P_{\text {BATMIN }}(\mathrm{kW})$ & -5.82 & -5.82 & -5.82 \\
$E_{S}(\mathrm{kWh})$ & 26.14 & 28.90 & 28.00 \\
\hline
\end{tabular}

generated by our synthesis process can be used in a sizing process (typically with an IOD approach) instead of the reference profile for the battery sizing (Tables 9-11).

\section{Synthesis and discussion}

Table 12 summarizes a comparison of the four battery sizing approaches using statistical and compact synthesis techniques.

It can be observed from this table that we roughly obtain the same battery size whatever the method used $(129 \leq<$ $\left.N_{B T}>\leq 134\right)$. The statistical methods lead to a reduction in the wind speed profile duration by a ratio of 2.85 (i.e. 70/200 days) and it can be clearly seen that the CPU time is also decreased. Methods using compact synthesis techniques provide better compacting factor and allow a significant reduction of the computational time versus statistical methods based on Monte Carlo 
Table 12

Comparison of the four battery sizing approaches.

\begin{tabular}{lllll}
\hline & Actual profile & $\begin{array}{l}\text { Duration (days) } \\
200\end{array}$ & $\begin{array}{l}\text { Time reduction } \\
1\end{array}$ & $\begin{array}{c}\text { Average nb. of battery cells }<N_{B T}> \\
132\end{array}$ \\
\hline \multirow{2}{*}{ Statistical approach } & Wind speed-based approach & 70 & 2.85 & 130 \\
\multirow{2}{*}{ Compact synthesis approach } & Output WT power-based approach & 70 & 2.85 & 129 \\
& System-based targets & 10 & 20 & 132 \\
& Wind-based targets & 10 & 20 & 134 \\
\hline
\end{tabular}

simulations. Indeed, the initial duration of the actual wind speed profile has been divided by 20 (i.e. 10/200 days). We conclude that approaches based on compact synthesis are highly efficient in terms of sizing accuracy and reduction of the wind speed profile duration. This offers significant gains in terms of computational time in the framework of the optimization process of such systems. Moreover, it has been shown that the use of the compact fictitious profiles resulting from these approaches leads to consistent constraints with respect to the battery cyclability.

\section{Conclusion}

In this paper, several methodologies for sizing a battery bank devoted to a stand-alone WT system have been developed and compared. The first two proposed sizing approaches take account of stochastic features of wind energy potential in a particular location with a given deterministic power demand. These approaches are based on the exploitation of wind speed distribution from a Weibull law or the extracted power histogram at the WT output. It has been shown that a robust sizing of the battery bank can be obtained from the stochastic generation of either the wind speed profile or the extracted WT output power using a specific algorithm. Two additional approaches have been developed for compacting wind speed profiles. These approaches consist in generating compact wind profiles by aggregating elementary parameterized segments in order to fulfill target indicators representing the features of a reference wind profile of longer duration. It has been shown that both latter approaches are able to represent the main features of the reference profile with respect to the wind farm potential and are also relevant for evaluating the critical conditions imposed on the battery storage (i.e. power and energy needs, number of cycles) in a hybrid WT system. All sizing methods lead roughly to the same battery size and the same cyclability features but with different wind profile durations. Statistical methods have provided a gain of 2.5 in time window reduction, while compact synthesis methods have led to a gain of 20. From these compact profiles, a subsequent reduction of the computation time should be obtained in the context of the optimization process of such systems.

\section{Acknowledgements}

This work was supported by the Tunisian Ministry of High Education, Research and Technology; CMCU - 12G1103 and by a SMI project of the INP Toulouse.

\section{References}

[1] Gavanidou E, Bakirtzis A. Design of a stand alone system with renewable energy sources using trade-off methods. IEEE Trans Energy Convers 1992;7(1):42-8. http://dx.doi.org/10.1109/60.124540.
[2] Chedid R, Rahman S. Unit sizing and control of hybrid wind-solar power systems. IEEE Trans Energy Convers 1997;12(1):79-85. http://dx.doi.org/ $10.1109 / 60.577284$.

[3] Kellogg W,D, Nehrir MH, Venkataramanan G, Gerez V. Generation unit sizing and cost analysis for stand-alone wind, photovoltaic and hybrid wind/PV systems. IEEE Trans Energy Convers 1998;13(1):70-5. http://dx.doi.org/ 10.1109/60.658206.

[4] Bernard-Agustín JL, Dufo-Lopez R, Rivas-Ascaso DM. Design of isolated hybrid systems minimizing costs and pollutant emissions. Renew Energy 2006;31(14):2227-44. http://dx.doi.org/10.1016/j.renene.2005.11.002.

[5] Senjyu T, Hayashi D, Yona A, Urasaki N, Funabashi T. Optimal configuration of power generating systems in isolated island with renewable energy. Renew Energy 2007;32:1917-33. http://dx.doi.org/10.1016/j.renene.2006.09.003.

[6] Yazdanpanah-Jahromi MA, Barakati S-M, Farahat S. An efficient sizing method with suitable energy management strategy for hybrid renewable energy systems. Int Trans Electr Energy Syst 2013. http://dx.doi.org/10.1002/etep.1790.

[7] Belfkira R, Nichita C, Reghem P, Barakat G. Modeling and optimal sizing of hybrid energy system. Int. Power Electronics and Motion Control Conference (EPE-PEMC). Poznan, Poland; 2008. p. 1834-39. http://dx.doi.org/10.1109/EPE PEMC.2008.4635532.

[8] Lim JH. Optimal combination and sizing of a new and renewable hybrid generation system. Int J Future Gener Commun Netw 2012;5(2):43-60.

[9] Sareni B, Abdelli A, Roboam X, Tran DH. Model simplification and optimization of a passive wind turbine generator. Renew Energy 2009;34:2640-50. http: //dx.doi.org/10.1016/j.renene.2009.04.024.

[10] Tran DH, Sareni B, Roboam X, Espanet C. Integrated optimal design of a passive wind turbine system: an experimental validation. IEEE Trans Sustain Energy 2010;1(1):48-56. http://dx.doi.org/10.1109/TSTE.2010.2046685.

[11] Gupta SC, Kumar Y, Agnihotri Gayatri. REAST: renewable energy analysis and sizing tool. J Electr Syst 2011;7(2):206-24.

[12] Protogeropoulos C, Brinkworth B, Marshall R. Sizing and techno-economical optimization for hybrid solar photovoltaic/wind power systems with battery storage. Int J Energy Res 1997;21:465-79. http://dx.doi.org/10.1002/(SICI) 1099-114X(199705)21:6 < 465::AID-ER273 > 3.0.CO;2-L.

[13] Morgan T, Marshall R, Brinkworth B. ARES - a refined simulation program for the sizing and optimization of autonomous hybrid energy systems. Sol Energy 1997;59(4-6):205-15. http://dx.doi.org/10.1016/S0038-092X(96)00151-X.

[14] Seeling-Hochmuth G. A combined optimization concept for the design and operation strategy of hybrid-PV energy systems. Sol Energy 1997;61(2):77-87. http://dx.doi.org/10.1016/S0038-092X(97)00028-5.

[15] Borowy BS, Salameh ZM. Optimum photovoltaic array size for a hybrid wind/ PV system. IEEE Trans Energy Convers 1994;9(3):482-8. http://dx.doi.org/ $10.1109 / 60.326466$.

[16] Borowy BS, Salameh ZM. Methodology for optimally sizing the combination of a battery bank and PV array in a Wind/PV hybrid system. IEEE Trans Energy Convers 1996;11(2):367-75. http://dx.doi.org/10.1109/60.507648.

[17] Bagul AD, Salameh ZM, Borowy BS. Sizing of a stand-alone hybrid windphotovoltaic system using a three-event probability density approximation. Sol Energy 1996;56(4):323-36. http://dx.doi.org/10.1016/0038-092X(95) 00116-9.

[18] Barkirtzis AG, Dokopoulos PS, Gavanidous ES, Ketselides MA. A probabilistic costing method for the evaluation of the performance of grid-connected wind arrays. IEEE Trans Energy Convers 1989;4(1):99-107. http://dx.doi.org/ $10.1109 / 60.23147$.

[19] Abouzar I, Ramakumar R. Loss of power supply probability of stand-alone wind electric conversion system: a closed form solution. IEEE Trans Energy Convers 1991;6(1):445-52. http://dx.doi.org/10.1109/60.105267.

[20] Bakirtzis AG. A probabilistic method for the evaluation of the reliability of stand-alone wind energy conversion system. IEEE Trans Energy Convers 1992;7(1):99-107. http://dx.doi.org/10.1109/60.124548.

[21] Conti S, Tina G, Vagliasindi U. A new method for estimating the long term average performance of hybrid Wind/PV systems. In: Proceedings of Eurosun. Copenhagen, Denmark. June 19-22; 2000.

[22] Jaafar A, Sareni B, Roboam X. Signal synthesis by means of Evolutionary algorithms. J Inverse Probl Sci Eng 2012;20(12):93-104. http://dx.doi.org/ 10.1080/17415977.2011.624619.

[23] Belouda M, Belhadj D, Sareni B, Roboam R, Jaafar A. Synthesis of a compact wind profile using evolutionary algorithms for wind turbine system with storage. MELECON'2012. Hammamet, Tunisia; 2012. http://dx.doi.org/10.1109/ MELCON.2012.6196464. 
[24] Fefermann Y, Randi SA, Astier S, Roboam X. Synthesis models of PM Brushless Motors for the design of complex and heterogeneous system. EPE'01. Graz, Austria. September; 2001

[26] 〈http://www.houseofbatteries.com/〉.

[27] Drouilhet S, Johnson BL. A battery life prediction method for hybrid power applications. In: Proceedings of the 35th AIAA Aerospace Sciences Meeting and Exhibit. Reno, USA; 1997.

[28] Dufo-Lopez R, Bernal-Agustin JL. Multi-objective design of PV-wind-dieselhydrogen-battery systems. Renew Energy 2008;33:2559-72. http://dx.doi. org/10.1016/j.renene.2008.02.027.

[29] Jaafar A, Akli CR, Sareni B, Roboam X, Jeunesse A. Sizing and energy management of a hybrid locomotive based on flywheel and accumulators. IEEE
Trans Veh Technol 2009;58(8):3947-58. http://dx.doi.org/10.1109/ TVT.2009.2027328.

[30] Downing SD, Socie DF. Simple rainflow counting algorithms. Int J Fatigue 1982;4(1):31-40. http://dx.doi.org/10.1016/0142-1123(82)90018-4.

[32] Roboam X, Abdelli A, Sareni B. Optimization of a passive small wind turbine based on mixed Weibull-turbulence statistics of wind. Electrimacs. Québec Canada; 2008.

[33] Petrowski A. A clearing procedure as a niching method for genetic algorithms. In: Proceedings of the IEEE international conference on evolutionary computation. Nagoya, Japan; 1996. p. 798-803. http://dx.doi.org/10.1109/ICEC. $\underline{1996.542703 .}$ 